\title{
The common pentanucleotide polymorphism of the 3 '-untranslated region of the leptin receptor gene is associated with obesity in Saudi females
}

\author{
Maha H. Daghestani ${ }^{1, \# \#, ~ M a z i n ~ H . ~ D a g h e s t a n i ~}{ }^{3}$, Pinar T. Ozand ${ }^{4}$, Ahmed R. Al-Himaidi ${ }^{5}$, \\ Mamoon H. Daghestani ${ }^{6}$, Nadia A. Aleisa ${ }^{1}$, Hana H. Hakami ${ }^{1}$, Abdelmoneim Eldali ${ }^{7}$, \\ Ali N. Al-odaib ${ }^{2}$ \\ ${ }^{1}$ Department of Zoology, Center for Scientific and Medical Female Colleges, King Saud University, Riyadh, KSA; \\ \#Corresponding Author: mdaghestani@ksu.edu.sa, naleisa@ksu.edu, hhakami1@ksu.edu.sa \\ ${ }^{2}$ Department of Genetics, King Faisal Specialist Hospital and Research Center, Riyadh, KSA; odaib@kfshrc.edu.sa \\ ${ }^{3}$ Department of Obstetrics \& Gynecology, Umm-Al-Qura University, Makkah, KSA; mhdaghestani@uqu.edu.sa \\ ${ }^{4}$ Duzen Laboratories, Istanbul, Turkey; pinar.ozand@gmail.com \\ ${ }^{5}$ Department of Zoology, Science College, King Saud University, Riyadh, KSA; ahimaidi@ksu.edu.sa \\ ${ }^{6}$ Department of Surgery, King Abdulaziz Medical City, National Guard Health Affairs, Jeddah, KSA; mdaghist@hotmail.com \\ ${ }^{7}$ Biostatistics, Epidemiology \& Scientific Computing (MBC-03), King Faisal Specialist Hospital and Research Center, Riyadh, KSA; \\ adalee@kfshrc.edu.sa
}

Received 5 November 2012; revised 4 December 2012; accepted 12 December 2012

\begin{abstract}
Obesity is due to the combined effects of genes, environment, lifestyle, and the interactions of these factors. Leptin receptor (LEPR) gene has been intensively evaluated in the search of variants that could be related to obesity. The results of most of these studies have been controversial. We investigated the effects of leptin receptor gene 3'-untranslated region (3'-UTR) polymorphism on phenotype, metabolic parameters and anthropometric measurements of obese Saudi females. 122 healthy women aged 19 to 36 years. The subjects were divided into 3 groups according to their body mass index $\mathrm{BMI}$; lean (BMI 18 - 24)' overweight (BMI 25 - 29) and obese (BMI $\geq 30$ ). There were 13 homozygotes and 34 heterozygotes for the 3'-UTR insertion allele amongst all 122 women. The results of this study show that the allele frequency of the insertion allele (I) of 3'UTR was significantly higher in overweight (35.3) and obese females (32.2) compared to the frequency in lean females (15.6). The insertion allele was associated with increased BMI in obese groups. The results obtained from this study indicated that in the obese subjects most variable values increased in I/I homozygote but the significant high value recorded among BMI $\left(40.9 \pm 7.11 \mathrm{~kg} / \mathrm{m}^{2}, P=\right.$ 0.042 ). Our findings indicated that, the obesity in
\end{abstract}

\footnotetext{
*The authors declare no conflict of interest.
}

Saudi females is influenced by alteration in the leptin receptor gene 3'-UTR polymorphism.

Keywords: Pentanucleotide; Polymorphism; Leptin; Obesity; Saudi Females

\section{INTRODUCTION}

Leptin, a peptide hormone encoded by the obesity gene [1], is produced by adipocytes to regulate body weight and energy balance $[2,3]$. In the fed state, circulating leptin concentrations reflect the magnitude of fat stores [4,5], and leptin levels are elevated in many models of animal obesity and in obese humans, correlating strongly with the degree of obesity [4-6]. Leptin acts through the leptin receptor (OB-R) [7] that is expressed in the nervous system and peripheral tissues such as adipose tissue, skeletal muscles, pancreatic $\beta$-cells, and liver. A single transcription unit of leptin receptor may serve to generate more than one protein. For instance, several isoforms can be derived from a single gene locus by alternative hnRNA splicing, including a long isoform expressed primarily in the hypothalamus and several shortisoforms with a much wider tissue distribution [7]. Although the frequency of such mutations is very low, common polymorphisms of the leptin and OB-R may well contribute to a common form of obesity and, as a consequence, obesity-related diseases $[8,9]$.

Mutations in the genes encoding leptin (ob) and its receptor $(\mathrm{db})$ have been found to cause early onset morbid obesity, with related phenotypes such as type 2 diabetes 
in animals [10] and humans $[11,12]$. The $O B-R$ gene is a polymorphic gene. Q223R (rs59347832), K109R (rs59932898), and K656N (rs8179183) are among the principal polymorphisms of this gene and are localized in the extracellular region of the receptor in exons 6,4 , and 14 , respectively. The trans-membrane region of the receptor is encoded by exon 18. A large number of studies have been able to associate some of these polymerphisms with body weight gain [13], metabolic carbohydrate reduction [14], lower body weight, body mass index (BMI), body fat, and smaller waist circumference [15]. Low body fat levels and elevated high-density cholesterol [16]. The Q223R polymorphism appears to contribute to a common form of obesity. In contrast, the K109R and K656N polymorphisms have been observed to be involved in the response to glucose and insulin [17].

Studies in obese subjects have reported that heterozygous carriers of a pentanucleotide insertion in the 3'UTR of the leptin receptor gene had lower serum insulin concentrations than the homozygous carriers of the more common deletion allele $[18,19]$.

Obese humans are characterized by increased circulating leptin levels $[5,6]$, suggesting that human obesity is associated with an insensitivity to endogenous leptin. Since a defect in the leptin-mediated signaling pathway, including the leptin receptor, could be the cause of leptin resistance, the leptin receptor gene has been a plausible candidate gene for obesity [6-20]. Therefore, we investigated the effects of leptin receptor gene 3'-UTR polymorphism on phenotype, metabolic parameters and anthropometric measurements of obese Saudi females.

\section{METHODS}

\subsection{Subjects}

Inclusion Criteria: Saudis, age above 18 years, gave consent to participate in the study, with no known illness. Exclusion criteria: non-Saudis, children, suffering from endocrine or genetic causes of obesity. One hundred and twenty two Saudi females' volunteers were participated in this study. After being informed of the purpose and procedures of the study, all subjects signed a consent form. The study protocol was approved by the KFSH \& RC Research Ethical committees. The subjects were divided into 3 groups according to their body mass index BMI; lean ( $\mathrm{n}=60$, BMI $\left.18.5-24 \mathrm{~kg} / \mathrm{m}^{2}\right)$, overweight ( $=17$, BMI $\left.25-29 \mathrm{~kg} / \mathrm{m}^{2}\right)$ and obese $(\mathrm{n}=45, \mathrm{BMI} \geq 30$ $\mathrm{kg} / \mathrm{m}^{2}$ ). The general characteristics of the subjects are summarized in Table 1. All subjects were healthy, free of any medication with regular menstrual cycle, and no history of gastrointestinal or endocrine disorders. After an overnight fast (12 hrs) a venous blood sample was obtained from all subjects in the morning between 08.00 $\mathrm{h}$ and $09.00 \mathrm{~h}$ for the determination of fasting serum leptin, insulin and glucose. Serum was aliquoted, and stored at $-80^{\circ} \mathrm{C}$ until required for assay.

\subsection{Anthropometry and Body Composition Measurement}

For all subjects, weight and height were measured to the nearest $0.5 \mathrm{~kg}$ and $0.5 \mathrm{~cm}$, respectively. Body mass index (BMI) was calculated as weight (kilograms)/height (meters) ${ }^{2}$. Waist and hip circumferences were measured to a precision of $0.1 \mathrm{~cm}$, and the waist to hip ratio was calculated [20].

\subsection{Analytical Method}

Plasma glucose was measured by a glucose oxidase method using the Roche Glucose HK liquid assay on Roche/Hitachi 917 automatic analyzer. Serum insulin was measured with electrochemiluminescence immunoassay "ECLIA" technique, using Elecsys insulin kit on E 170 immunoassay analyzer (Roche). Serum leptin was measured in duplicate using human leptin ELISA kit from Linco Research, Inc. (St. Charles, MO), with a lower limit of detection of $0.5 \mathrm{ng} / \mathrm{mL}$.

Table 1. Mean comparisons of clinical and endocrine-metabolic characteristics between lean, overweight and obese groups.

\begin{tabular}{|c|c|c|c|c|c|}
\hline Variable & $\begin{array}{c}\text { Control lean } \\
(\mathrm{n}=60) \text { mean } \pm \mathrm{SE}\end{array}$ & $\begin{array}{c}\text { Overweight } \\
(\mathrm{n}=17) \text { mean } \pm \mathrm{SE}\end{array}$ & $\mathrm{p}$ value & $\begin{array}{c}\text { Obese } \\
(\mathrm{n}=45) \text { mean } \pm \mathrm{SE}\end{array}$ & $\mathrm{p}$ value \\
\hline Age (yr.) & $23.95 \pm 0.60$ & $21.59 \pm 0.94$ & 0.06 & $26.49 \pm 0.96$ & 0.028 \\
\hline BMI $\left(\mathrm{kg} / \mathrm{m}^{2}\right)$ & $20.85 \pm 0.25$ & $27.38 \pm 0.37$ & $<0.0001$ & $35.90 \pm 0.92$ & $<0.0001$ \\
\hline Waist (cm) & $66.85 \pm 0.70$ & $81.59 \pm 1.82$ & $<0.0001$ & $100.29 \pm 2.14$ & $<0.0001$ \\
\hline Hip (cm) & $94.59 \pm 0.91$ & $105.29 \pm 1.78$ & $<0.0001$ & $121.96 \pm 2.14$ & $<0.0001$ \\
\hline WH ratio & $0.71 \pm 0.01$ & $0.78 \pm 0.01$ & $<0.0001$ & $0.82 \pm 0.01$ & $<0.0001$ \\
\hline Leptin (ng/ml) & $11.70 \pm 0.46$ & $23.79 \pm 1.55$ & $<0.0001$ & $46.04 \pm 3.07$ & $<0.0001$ \\
\hline Fasting insulin $(\mathrm{pmol} / \mathrm{L})$ & $52.57 \pm 2.29$ & $63.93 \pm 9.95$ & 0.09 & $104.69 \pm 5.58$ & $<0.0001$ \\
\hline Fasting glucose (mmol/L) & $4.54 \pm 0.05$ & $4.66 \pm 0.15$ & 0.32 & $4.99 \pm 0.07$ & $<0.0001$ \\
\hline
\end{tabular}




\subsection{DNA Analysis}

The 3'-UTR pentanucleotide insertion/deletion polymorphism of the leptin receptor gene was analysed from DNA extracted from EDTA-anticoagulated venous blood samples using the QIAamp DNA Blood Mini Kit (QIAgen Inc., Santa Clarita, CA). A DNA fragment of 114 or $119 \mathrm{bp}$ in size (depending on the absence or presence of the insertion) was generated by polymerase chain reaction using 5' mismatch primer ATAATGGGTAATATAAAGTGTAATAGAGTA and 3' primer AGAGAACAAACAGACAACATT, and analysed as described in detail previously [19]. To confirm the results, all heterozygous, homozygous and 10 samples from each group of common deletion allele were sequenced. Oligonucleotides primers were designed using web primer DNA and purpose entry

(http://seq.yeastgenome.org/cgi-bin/SGD/web-primer) Forward primer II. 5'-GACTTTTGCATCTTACATGCC-3'Reverse primer II. 5'-ATTGGTAGGCTTATGAA -3 '. The PCR conditions consisted of an initial denaturation step at $95^{\circ} \mathrm{C}$ for 15 minutes, followed by 34 cycles of denaturation at $95^{\circ} \mathrm{C}$ for 1 minute, annealing at $60^{\circ} \mathrm{C}$ for 1 minute, and extension at $72^{\circ} \mathrm{C}$ for 1 minute, with a final extension of 10 minutes at $72^{\circ} \mathrm{C}$, sequencing was performed with the BigDye Terminator Cycle Sequencing Ready Reaction Kit (Applied Biosystems, Foster City, CA) on the ABI 3100 Genetic Analyzer (Applied Biosystems).

\subsection{Statistical Analysis}

Data are presented as mean \pm SEM. The comparisons between obese subjects and matched control were done using the independent t-test and ANOVA test. The distributions of the age, BMI, anthropometric measurements, fasting serum insulin, leptin and glucose values of the study subjects according to their leptin receptor 3'-UTR genotype of each group were compared by the U MannWhitney test. Frequency distribution analysis was performed with chi square test. A probability value $\mathrm{p} \leq 0.05$ was considered statistically significant. All analyses were run using the StatView program for Windows (version 8.0; SAS).

\section{RESULTS}

The mean age, BMI, anthropometric, mean leptin, insulin concentrations, and fasting glucose of the groups are shown in Table 1. As presented in Table 1 student's t-test was applied and significant differences were found in the waist, hip and waist/hip ratio among over weight and obese subjects compared with lean control group. Serum concentrations of leptin were markedly and significantly higher in obese, overweight subjects compared with lean controls. Serum fasting glucose and insulin levels were significantly higher in obese group compared to controls, no significantly different between overweight and lean groups (Table 1).

The genotype distribution and allele frequencies for the insertion/delition 3'UTR polymorphisms of the LEPR gene are presented in Table 2. The genotype distribution was governed by Hardy-Weinberg equilibrium law in this study. As shown in table there were 13 homozygotes and 34 heterozygotes for the 3'-UTR insertion allele amongst all 122 women. The results of this study show that the allele frequency of the insertion allele (I) of 3'UTR was significantly higher in overweight (35.3) and obese females (32.2) compared to the frequency in lean females (15.6). The frequency of the (D) allele in the lean group was $84.2 \%, 64.7 \%$ in the overweight group and $67.8 \%$ in the obese group, whereas the frequency of the (I) allele in the different weight groups was $15.8 \%$ in the lean group, $35.3 \%$ in the overweight group and $32.2 \%$ in the obese group. When overweight and obese results were compared to lean, the $x^{2}$ was $\mathrm{p}=$ 0.01 and $p=0.005$, respectively, and the difference was statistically significant (Table 2).

The distributions of the age, BMI, anthropometric measurements, fasting serum insulin, leptin and glucose values of the study subjects according to their leptin receptor 3'-UTR genotype of each group are presented in Tables 3-5 in the obese subjects most variable values

Table 2. 3'UTR pentanucleotide insertion/deletion polymorphism of the human leptin receptor gene. Genotype and allele frequencies in lean, over weight and obese subjects.

\begin{tabular}{|c|c|c|c|c|c|}
\hline \multirow{2}{*}{ 3'UTR } & \multirow{2}{*}{$\begin{array}{c}\text { Control lean } \\
\text { Frequency (\%) }\end{array}$} & \multicolumn{2}{|c|}{ Overweight } & \multicolumn{2}{|c|}{ Obese } \\
\hline & & Frequency $(\%)$ & $\mathrm{p}$ value & Frequency $(\%)$ & $\mathrm{p}$ value \\
\hline Genotype D/D & $43(71.67 \%)$ & $9(52.94 \%)$ & \multirow{3}{*}{0.02} & $23(51.11 \%)$ & \multirow{3}{*}{0.03} \\
\hline Genotype D/I & $15(25 \%)$ & $4(23.53 \%)$ & & $15(33.33 \%)$ & \\
\hline Genotype I/I & $2(3.33 \%)$ & $4(23.53 \%)$ & & $7(15.56 \%)$ & \\
\hline Allele D & $(84.2 \%)$ & $(64.7 \%)$ & \multirow{2}{*}{0.01} & $(67.8 \%)$ & \multirow{2}{*}{0.005} \\
\hline Allele I & $(15.8 \%)$ & $(35.3 \%)$ & & $(32.2 \%)$ & \\
\hline
\end{tabular}


Table 3. Leptin receptor gene 3'UTR deletion/insertion polymorphism in relation to anthropometry, hormone and metabolic variables in control lean group.

\begin{tabular}{lcccc}
\hline Variables & $\mathrm{D} / \mathrm{D}(\mathrm{n}=43)$ & $\mathrm{D} / \mathrm{I}(\mathrm{n}=15)$ & $\mathrm{I} / \mathrm{I}(\mathrm{n}=2)$ & $\mathrm{p}$-value \\
\hline Age (years) & $23.0 \pm 4.35$ & $26.0 \pm 4.50$ & $27.0 \pm 9.90$ & 0.064 \\
BMI $\left(\mathrm{kg} / \mathrm{m}^{2}\right)$ & $20.7 \pm 1.95$ & $21.1 \pm 1.95$ & $21.0 \pm 1.41$ & 0.768 \\
Waist $(\mathrm{cm})$ & $67.2 \pm 5.39$ & $65.7 \pm 5.65$ & $66.0 \pm 5.66$ & 0.627 \\
Hip $(\mathrm{cm})$ & $94.5 \pm 7.12$ & $95.1 \pm 6.94$ & $92.5 \pm 10.6$ & 0.877 \\
W/H ratio & $0.71 \pm 0.042$ & $0.69 \pm 0.049$ & $0.71 \pm 0.014$ & 0.302 \\
Leptin (ng/ml) & $11.7 \pm 3.86$ & $11.4 \pm 3.13$ & $11.7 \pm 0.35$ & 0.948 \\
Fasting insulin (pmol/L) & $53.1 \pm 18.9$ & $50.0 \pm 15.0$ & $59.2 \pm 7.42$ & 0.736 \\
Fasting glucose (mmol/L) & $4.56 \pm 0.39$ & $4.50 \pm 0.40$ & $4.35 \pm 0.21$ & 0.700 \\
\hline
\end{tabular}

Table 4. Leptin receptor gene 3'UTR deletion/insertion polymorphism in relation to anthropometry, hormone and metabolic variables in overweight group.

\begin{tabular}{lcccc}
\hline Variables & $\mathrm{D} / \mathrm{D}(\mathrm{n}=9)$ & $\mathrm{D} / \mathrm{I}(\mathrm{n}=4)$ & $\mathrm{I} / \mathrm{I}(\mathrm{n}=4)$ & $\mathrm{p}$-value \\
\hline Age $(\mathrm{years})$ & $22.4 \pm 5.13$ & $20.75 \pm 1.26$ & $20.50 \pm 1.73$ & 0.640 \\
BMI $\left(\mathrm{kg} / \mathrm{m}^{2}\right)$ & $27.1 \pm 1.63$ & $27.90 \pm 1.33$ & $27.48 \pm 1.60$ & 0.471 \\
Waist $(\mathrm{cm})$ & $80.8 \pm 7.52$ & $85.50 \pm 7.14$ & $79.25 \pm 8.22$ & 0.380 \\
Hip $(\mathrm{cm})$ & $103.5 \pm 8.68$ & $107.75 \pm 3.77$ & $106.75 \pm 7.32$ & 0.576 \\
W/H ratio & $0.78 \pm 0.047$ & $0.80 \pm 0.055$ & $0.74 \pm 0.075$ & 0.341 \\
Leptin (ng/ml) & $22.7 \pm 6.28$ & $24.2 \pm 7.09$ & $26.3 \pm 7.37$ & 0.716 \\
Fasting insulin $(\mathrm{pmol} / \mathrm{L})$ & $66.7 \pm 45.7$ & $69.5 \pm 45.7$ & $46.0 \pm 17.7$ & 0.729 \\
Fasting glucose $(\mathrm{mmol} / \mathrm{L})$ & $4.55 \pm 0.65$ & $4.78 \pm 0.50$ & $4.80 \pm 0.75$ & 0.755 \\
\hline
\end{tabular}

Table 5. Leptin receptor gene 3'UTR deletion/insertion polymorphism in relation to anthropometry, hormone and metabolic variables in obese group.

\begin{tabular}{|c|c|c|c|c|}
\hline Variables & $\mathrm{D} / \mathrm{D}(\mathrm{n}=23)$ & $\mathrm{D} / \mathrm{I}(\mathrm{n}=15)$ & $\mathrm{I} / \mathrm{I}(\mathrm{n}=7)$ & p-value \\
\hline Age (years) & $26.9 \pm 6.77$ & $25.6 \pm 6.23$ & $26.8 \pm 6.67$ & 0.815 \\
\hline BMI $\left(\mathrm{kg} / \mathrm{m}^{2}\right)$ & $35.6 \pm 6.33$ & $33.9 \pm 4.17$ & $40.9 \pm 7.11$ & 0.042 \\
\hline Waist (cm) & $101.0 \pm 16.0$ & $94.7 \pm 6.47$ & $109.7 \pm 16.7$ & 0.066 \\
\hline Hip (cm) & $121.1 \pm 16.1$ & $118.7 \pm 10.5$ & $131.5 \pm 12.6$ & 0.137 \\
\hline $\mathrm{W} / \mathrm{H}$ ratio & $0.83 \pm 0.044$ & $0.80 \pm 0.045$ & $0.83 \pm 0.068$ & 0.163 \\
\hline Leptin (ng/ml) & $44.1 \pm 19.7$ & $40.5 \pm 12.7$ & $64.1 \pm 28.7$ & 0.31 \\
\hline Fasting insulin $(\mathrm{pmol} / \mathrm{L})$ & $111.0 \pm 34.1$ & $90.8 \pm 37.2$ & $113.4 \pm 45.1$ & 0.214 \\
\hline Fasting glucose $(\mathrm{mmol} / \mathrm{L})$ & $5.03 \pm 0.45$ & $4.96 \pm 0.40$ & $4.88 \pm 0.54$ & 0.723 \\
\hline
\end{tabular}

increased in $\mathrm{I} / \mathrm{I}$ homozygote but the significant high value recorded among BMI $\left(40.9 \pm 7.11 \mathrm{~kg} / \mathrm{m}^{2}, \mathrm{p}=\right.$ 0.042).

\section{DISCUSSION}

Since 1997, several single nucleotide polymorphisms (SNPs) in coding region and a pentanucleotide (CTTTA) insertion/deletion polymorphism in the 3'-untranslated region of the human OB-R gene have been reported in different ethnic groups [21-25]. Two studies confirmed the existence of the CTTTA pentanucleotide I/D polymorphism at the 3'UTR of the OB-R gene $[18,19]$.
Leptin gene and leptin receptorgene products, respectively, have defined a new biological pathway for the regulation of food intake and energy expenditure. Leptin acts at distinct sites and through different mechanisms within the central nervous system (CNS) to mediate energy homeostasis and feeding behavior [26,27]. It appears that leptin controls feeding not just by providing physiological satiety signal, but also by mediating "synaptic plasticity" as well as modulating the perception of reward associated with feeding [26-28].

This is the first study to suggest an association between a polymorphism of the leptin receptor gene and 
obesity. The present study revealed significant differences in allele and genotype frequencies between the normal group on one hand and overweight and obese groups on the other hand $(\mathrm{p}<0.05)$. The allele frequency of the insertion allele was higher in overweight $(0.35)$ and obese females (32.2) when compared to the frequency in lean females (15.6). In contrast to our findings a previous study performed on Finnish individuals showed that there was no significant difference in the frequency of the insertion allele (I) between obese (0.124) and normal weight subjects (0.120) [29]. In the Finnish study, four obese, but none of the normal weight subjects were homozygous for the insertion allele [29]. In our study, 5 of the overweight and 9 obese individuals were homozygous for the insertion allele and 3 of the normal weight individuals were also homozygous. Our results show significant differences in the genotype and allele frequency of leptin receptor gene pentanucleotide polymorphism in Saudi females compared to the Finnish population. This pointed to genetic variations in the leptin receptor gene polymorphism between populations. The results of this study show that the insertion allele could be considered as a marker for obesity in Saudi females. Even though, the insertion allele also occurs at a fairly high frequency in non-obese Saudis, these results indicate that it can be used as a significant marker of obesity in Saudis, due to the fact that, it may be possible that these normal weight individuals have a higher sensitivity to develop obesity, but since they are avoiding the precipitating environmental factors, they are not obese. In addition, they may develop obesity more easily in older age if the predisposing factors are present. This confirmation requires a long-term investigation and follow-up studies on individuals with different alleles of the leptin receptor gene, which is a major problem with a study of genetic markers for non-communicable diseases. A person with a particular genotype may not have the disease at present, but may be susceptible to it or may develop it later.

The association of pentanucleotide insertion/deletion polymorphism with metabolic parameters and anthropometric measurements was earlier studied by many researchers, [29] reported better insulin sensitivity in obese subjects carrying the I allele because they had lower insulin and insulin-to-glucose ratio levels. [25] concluded that obese heterozygous women had lower insulin values at 30 minutes in the oral glucose tolerance test (OGTT). [29] found that healthy men carrying the I allele had a $79 \%$ reduced risk of type 2 diabetes. A Finnish study had shown that the carriers of the insertion allele had a $79 \%$ reduced risk of diabetes when compared to non-carriers; this is due to the lesser extent of leptin's action on the pancreatic $\beta$-cells to inhibit insulin secretion. The study revealed that this 3 '-UTR insertion was common in the healthy population since the carrier frequency was a high as $23.5 \%$ amongst the controls [29].

In contrast to previous reports [20] did not find a relationship between the I/D LEPR polymorphism and the con- version to type 2 diabetes. However, they found that the I allele was associated with greater reduction in weight, BMI, and waist circumference during the 3-year follow-up. Similarly, [31] reported that the association between I/D-LEPR and prevalent impaired glucose tolerance or type 2 diabetes did not reach statistical significance, and they did not find significant associations with other features of the metabolic syndrome.

Interestingly, the results of this study demonstrate that there was no association of serum leptin, glucose or insulin levels with the pentanucleotide genotype in the obese individuals. However, most variable values increased in I/I homozygote but the significant high value recorded among BMI $\left(40.9 \pm 7.11 \mathrm{~kg} / \mathrm{m}^{2}, \mathrm{P}=0.042\right)$. It is unfortunate that there have been no functional studies on the effects of this 3'-UTR polymorphism. Although stemloop sequences usually de-stabilize mRNA [30-32], it is unclear whether those in 3'-UTR of the leptin receptor gene, which would be formed by the pentanucleotide insertion allele, might stabilize or de-stabilize the mRNA. [19] hypothesized that this polymorphism might stabilize the mRNA level of the leptin receptor.

\section{CONCLUSION}

The results obtained from this study indicated that in the obese subjects most variable values increased in I/I homozygote but the significant high value recorded among BMI $\left(40.9 \pm 7.11 \mathrm{~kg} / \mathrm{m}^{2}, \mathrm{p}=0.042\right)$. Our findings support the hypothesis that alterations in the leptin signaling system could contribute to the obesity in Saudi Females.

\section{ACKNOWLEDGEMENTS}

This research project was supported by a grant from the "Research Center of the Center for Female Scientific and Medical Colleges", Deanship of Scientific Research, King Saud University.

\section{REFERENCES}

[1] Zhang, Y., Proenca, R., Maffei, M., Barone, M., Leopold, L. and Friedman, J.M. (1994) Positional cloning of the mouse obese gene and its human homologue. Nature, 372, 425-432. doi:10.1038/372425a0

[2] Campfield, L.A., Smith, F.J., Guisez, Y., Devos, R. and Burn, P. (1995) Recombinant mouse OB protein: Evidence for a peripheral signal linking adiposity and central neutral networks. Science, 269, 546-549. doi:10.1126/science.7624778

[3] Pelleymounter, M.A., Cullen, M.J., Baker, M.B., Hecht, R., Winters, D., Boone, T. and Collins, F. (1995) Effects 
of the obese gene product on body weight regulation in ob/ob mice. Science, 269, 540-543.

doi:10.1126/science. 7624776

[4] Frederich, R.C., Lollmann, B., Hamann, A., NapolitanoRosen, A., Kahn, B.B., Lowell, B.B. and Flie, J.S. (1995) Expression of ob mRNA and its encoded protein in rodents. Journal of Clinical Investigation, 96, 1658-1663. doi:10.1172/JCI118206

[5] Maffei, M., Halaas, J., Ravussin, E., Pratley, R.E., Lee, G.H., Zhang, Y., Fei, H., Kim, S., Lallone, R., Ranganathan, S., Kern, P.A. and Friedman, J.M. (1995) Leptin levels in human and rodent: Measurement of plasma leptin and ob RNA in obese and weight-reduced subjects. Nature Medicine, 1, 1155-1161. doi:10.1038/nm1195-1155

[6] Considine, R.V., Sinha, M.K., Heiman, M.L., Kriauciunas, A., Stephens, T.W., Nyce, M.R., Ohannesian, J.P., Marco, C.C., McKee, L.J., Bauer, T.L. and Caro, J.F. (1996) Serum immunoreactive-leptin concentrations in normalweight and obese humans. New England Journal of Medicine, 334, 292-295. doi:10.1056/NEJM199602013340503

[7] Chung, W.K., Power-Kehoe, L., Chua, M., Chu, F., Aronne, L., Huma, Z., Sothern, M., Udall, J.N., Kahle, B. and Leibel, R.L. (1997) Exonic and intronic sequence variation in the human leptin receptor gene (LEPR). Diabetes, 46, 1509-1511.

[8] Guízar-Mendoza, J.M., Amador-Licona, N., Flores-Martínez, S.E., López-Cardona, M.G., Ahuatzin-Trémary, R. and Sánchez-Corona, J. (2005) Association analysis of the Gln223Arg polymorphism in the human leptin recaptor gene, and traits related to obesity in Mexican adolescents. Journal of Human Hypertension, 19, 341-346. doi:10.1038/sj.jhh.1001824

[9] van der Vleuten, G.M., Kluijtmans, L.A., Hijmans, A., Blom, H.J., Stalenhoef, A.F. and de Graaf, J. (2006) The Gln223Arg polymorphism in the leptin receptor is associated with familial combined hyperlipidemia. International Journal of Obesity (Lond), 30, 892-898.

[10] Friedman, J.M. and Halaas, J.L. (1998) Leptin and the regulation of body weight in mammals. Nature, 395, 763770. doi: $10.1038 / 27376$

[11] Montague, C.T., Farooqi, I.S., Whitehead, J.P., Soos, M.A., Rau, H., Wreham, N.J., Sewter, C.P., Digby, J.E., Mohammed, S.N., Hurst, J.A., Cheetham, C.H., Early, A.R., Barnett, A.H., Prins, J.B. and O'Rahilly, S. (1997) Congenital leptin deficiency is associated with severe earlyonset obesity in humans. Nature, 387, 903-908. doi:10.1038/43185

[12] Wauters, M., Mertens, I., Chagnon, M., Rankinen, T., Considine, R.V., Chagnon, Y.C., Van Gaal, L.F. and Bouchard, C. (2001) Polymorphisms in the leptin receptor gene, body composition and fat distribution in overweight and obese women. International Journal of Obesity and Related Metabolic and Disorders, 25, 714-720. doi:10.1038/sj.ijo.0801609

[13] van Rossum, C.T., Hoebee, B., van Baak, M.A., Mars, M., Saris, W.H. and Seidell, J.C. (2003) Genetic variation in the leptin receptor gene, leptin, and weight gain in young
Dutch adults. Obesity and Research, 11, 377-386. doi:10.1038/oby.2003.51

[14] Wauters, M., Considine, R.V., Chagnon, M., et al. (2002) Leptin levels, leptin receptor gene polymorphisms, and energy metabolism in women. Obesity and Research, 10, 394-400. doi:10.1038/oby.2002.54

[15] de Luis Roman, D., de la Fuente, R.A., Sagrado, M.G., Izaola, O. and Vicente, R.C. (2006) Leptin receptor Lys656Asn polymorphism is associated with decreased leptin response and weight loss secondary to a lifestyle modification in obese patients. Archives of Medical Research, 37, 854-859. doi:10.1016/j.arcmed.2006.03.009

[16] Angel-Chávez, L.I., Tene-Pérez, C.E. and Castro, E. (2012) Leptin receptor gene $\mathrm{K} 656 \mathrm{~N}$ polymorphism is associated with low body fat levels and elevated high-density cholesterol levels in Mexican children and adolescents. Endocrine Research, 37, 124-134.

[17] Wauters, M., Mertens, I., Rankinen, T., Chagnon, M., Bouchard, C. and VanGaal, L. (2001) Leptin receptor gene polymorphisms are associated with insulin in obese women with impaired glucose tolerance. Journal of Clinical Endocrinology \& Metabolism, 86, 3227-3232. doi:10.1210/jc.86.7.3227

[18] Francke, S., Clement, K., Dina, C., Inoue, H., Behn, P., Vatin, V., Basdevant, A., Guy-Grand, B., Permutt, M.A., Froguel, P. and Hager, J. (1997) Genetic studies of the leptin receptor gene in morbidly obese French Caucasian families. Human Genetics, 100, 491-496. doi:10.1007/s004390050540

[19] Oksanen, L., Kaprio, J., Mustajoki, P. and Kontula, K.A. (1998) common pentanucleotide polymorphism of the 3'untranslated part of the leptin receptor gene generates a putative stem-loop motif in the mRNA and is associated with serun insulin levels in obese individuals. International Journal of Obesity, 22, 634-640. doi:10.1038/sj.ijo.0800639

[20] WHO (1988) Measuring obesity: Classification and description of anthropometric data. Copehhagen, WHO, EUR/ ICP/NUT 125.

[21] Matsuoka, N., Ogawa, Y., Hosada, K., Matsuda, J., Masuzaki, H., Miyawaki, T., Azuma, N.N., Natsui, K., Nishimura, H., Yoshimasa, Y., Nishi, N., Thompson, D.B. and Nakao, K. (1997) Human leptin receptor gene in obese Japanese subjects: Evidence against either obesity-causing mutations or association of sequence variants with obesity. Diabetologia, 40, 1204-1210. doi: $10.1007 / \mathrm{s} 001250050808$

[22] Thompson, D.B., Ravussin, E., Bennett, P.H. and Bogardus, C. (1997) Structure and sequence variation at the human leptin receptor gene in lean and obese Pima Indians. Human Molecular Genetics, 6, 675-679. doi: $10.1093 / \mathrm{hmg} / 6.5 .675$

[23] Quinton, N.D., Lee, A.J., Ross, R.J.M., Eastell, R. and Blakemore, A.I.F. (2001) A single nucleotide polymerphism (SNP) in the leptin receptor is associated with BMI, fat mass and leptin levels in postmenopausal Caucasian women. Human Genetics, 108, 233-236. doi:10.1007/s004390100468

[24] Heo, M., Leibel, R.L., Fontaine, K.R., Boyer, B.B., Chung, 
W.K., Koulu, M., Karvonen, M.K., Pesonen, U., Rissanen, A., Laakso, M., Uusitupa, M.I., Chagnon, Y., Bouchard, C., Donohoue, P.A., Burns, T.L., Shuldiner, A.R., Silver, K., Andersen, R.E.R.E., Pedersen, O., Echwald, S., Sorensen, T.L., Behn, P., Permutt, M.A., Jacobs, K.B., Elston, R.C., Hoffman, D.J., Gropp, E. and Allison, D.B. (2002) A meta-analytic investigation of linkage and association of common leptin receptor (LEPR) polymorphisms with body mass index and waist circumference. International Journal of Obesity and Related Metabolic Disorders, 26, 640-646. doi:10.1038/sj.ijo.0801990

[25] Lakka, H.M., Oksanen, L., Tuomainen, T.P., Kontula, K. and Salonen, J.T. (2000) The common pentanucleotide polymorphism of the 3-untranslated region of the leptin receptor gene is associated with serum insulin level and the risk of type 2 diabetes in non-diabetic men, a prospective case-control study. Journal of Internal Medicine, 248, 77-83. doi:10.1046/j.1365-2796.2000.00696.x

[26] Oswal, A. and Yeo, G. (2010) Leptin and the control of body weight: A review of its diverse central targets, signaling mechanisms, and role in the pathogenesis of obesity. Obesity (Silver Spring), 18, 221-229. doi:10.1038/oby.2009.228

[27] Huang, H., Kong, D., Byun, K.H., Ye, C., Koda, S., Lee, D.H., Oh, B.C., Lee, S.W., Lee, B., Zabolotny, J.M., Kim, M.S., Bjørbæk, C., Lowell, B.B. and Kim, Y.B. (2012) Rho-kinase regulates energy balance by targeting hypo- thalamic leptin receptor signaling. Nature Neuroscience, 15, 1391-1398. doi:10.1038/nn.3207

[28] Velloso, L.A. and Schwartz, M.W. (2011) Altered hypothalamic function in diet-induced obesity. International Journal of Obesity (Lond), 35, 1455-1465. doi:10.1038/ijo.2011.56

[29] Zacharova, J., Todorova, B.R., Chiasson, J.L. and Laakso, M. (2005) The G-250A substitution in the promoter region of the hepatic lipase gene is associated with the conversion from impaired glucose tolerance to type 2 diabetes: The STOP-NIDDM trial. Journal of Internal Medicine, 257, 185-193. doi:10.1111/j.1365-2796.2004.01435.x

[30] Nannipieri, M., Posadas, R., Williams, K., Politi, E., Gonzales-Villalpando, C., Stern, M.P. and Ferrannini, E. (2003) Association between polymorphisms of the atrial natriuretic peptide gene and proteinuria: A populationbased study. Diabetologia, 46, 429-432.

[31] Ross, J. (1995) mRNA stability in mammalian cells. Microbiological Review, 59, 423-450.

[32] Brown, C.Y., Lagnado, C.A. and Goodall, G.J. (1996) A cytokine mRNA-destabilizing element that is structurally and functionally distinct from A + U-rich elements. Proceedings of the National Academy Sciences USA, 93, 1372113725 . 